E-ISSN: 2808-5361

http://e-journal.fkmumj.ac.id/
Proceeding The First Muhammadiyah InternasionalPublic Health and Medicine Conference

\title{
Factors Related to Behavior Handwashing Using Primary-School-Age Children's Soap on Rt's Covid-19 Pandemic. 008/Rw. 007 Bananas, Ciputat Timur in 2021
}

\author{
${ }^{1}$ Leandra Binar Ilyasa, ${ }^{2}$ Andriyani, ${ }^{3}$ Nur Romdhona, ${ }^{4}$ Ernyasih \\ ${ }^{1-4}$ Faculty of Public Health, Muhammadiyah University of Jakarta \\ K.H. Ahmad Dahlan Street, Cireundeu, Ciputat, South Jakarta, 15415 \\ Email: leandrabinar@gmail.com
}

\begin{abstract}
About $40 \%$ of the world's human population has no place in their homes to wash their hands with soap and water. The prevalence of handwashing behavior with soap for school children in Indonesia in 2018 was 46\%. In 2018 the behavior of washing hands with soap in Banten Province in the group of school children was 44.5\%. South Tangerang City has a prevalence of handwashing behavior with soap in school children in 2018 of 69.12\%. This research was conducted to Factors Related to the Behavior of Washing Hands with Soap for Elementary School Age Children During the COVID-19 Pandemic at RT.008/RW.007 Pisangan, East Ciputat in 2021. Cross-sectional study design with 86 people as samples, the sampling done by total sampling technique. Data analysis used chi-square test $(\alpha=0.05)$. Variables related to the handwashing behavior with soap are knowledge ( $p$-value 0,038. OR=3,4), facilities ( $p$-value $=0,000 . O R=76,3)$, the role of parents ( $p$-value = 0,005 . OR=4,5). While variables not related to handwashing behavior with soap are attitude ( $p$ value $=0,132$. OR = 8,1). Factors Related to the Behavior of Washing Hands with Soap at RT.008 RW.007 Pisangan, East Ciputat are knowledge, facilities, the role of parents. An active parental role is needed so that they can guide, teach and be an example for their children in good handwashing behavior with soap. There is a need for prevention actions such as the distribution of handwashing soap and pamphlets containing an invitation to wash hands and this activity is under the supervision of the Pisangan Health Center
\end{abstract}

Keyword: Handwashing Behavior with Soap, Elementary School Age Children, COVID-19 
E-ISSN: 2808-5361

http://e-journal.fkmumj.ac.id/
Proceeding The First Muhammadiyah InternasionalPublic Health and Medicine Conference

\section{INTRODUCTION}

Clean and Healthy Living Behavior (PHBS) is one of the government programs to improve the degree of public health. One part of the PHBS program is handwashing using soap (Kemenkes RI, 2016). Handwashing using soap is one of the sanitary measures to break the germ chain by cleaning the hands and fingers using water and soap. Washing hands with soap is one of the efforts in disease prevention, this is done because the hands are often agents that carry germs and cause pathogens to move from one person to another, either by direct contact or indirect contact (Kemenkes RI, 2014).

According to the World Health Organization (2020b) that about $40 \%$ of the world's human population has no place in their homes to wash their hands with water and soap. Based on the National Basic Health Research of the Ministry of Health (2018a) that handwashing behavior in Indonesia in the characteristics of the age group of 10-14 years by $43 \%$ and the school children group by $46 \%$ do handwashing with soap and clean water.

Based on the results of Basic Health Research of Banten Province Kemenkes (2018b) handwashing behavior in Banten in the characteristics of the age group of 10-14 years by $42 \%$ and the school children group by $44.5 \%$. In South Tangerang City the proportion of good and correct handwashing behavior in 2018 was $69.12 \%$.

Handwashing activities with soap are the most effective way to prevent diarrhea and the main death of children. Every year, as many as 3.5 million children around the world die before reaching the age of five due to diarrheal diseases and ISPA (Kemenkes RI, 2014). School-age children are an age that is prone to various diseases, especially those related to the stomach, such as diarrhea, diarrhea, and others. The habit of children to consume snacks freely, plus children do not wash their hands with soap before eating will cause various germs that cause disease easily into the body because the hands are the part of our body that is most polluted with dirt and disease seeds. If this problem is not considered, it will increase the risk of diseases such as diarrhea, diarrhea, diarrhea, and so on (Kartika, et al., 2016).

According to Notoatmodjo (2010a), health behavior has several related factors including predisposing factors, supporting factors, and driving factors. In the behavior of handwashing using soap factors that affect, among others, namely knowledge, attitudes, facilities or facilities available, and the role of parents. Based on research Kartika et al. (2016) showed a relationship between knowledge and the behavior of handwashing using soap. Research conducted by Livana et al. Kota Lampung showed that there is a relationship between attitudes with the behavior of handwashing using soap. Research conducted on elementary school students in the working area of Banyuurip Purworejo Health Center by Mukminah et al. (2016) that Chi-Square Test showed a p-value of 0.046 which means there is a relationship between the availability of CTPS facilities and handwashing behavior using soap. Research conducted by Norfai (2017) on elementary students in Banjarmasin 
City conducted a statistical test of the relationship between the role of parents and the correct behavior of handwashing using soap.

PHBS became the main focus during the Corona Virus Disease 2019 (COVID-19) pandemic. Prevention by applying the $3 \mathrm{M}$ health protocol (Washing hands with soap, maintaining distance, wearing masks) has also been socialized by the Ministry of Health of the Republic of Indonesia to the public to avoid COVID-19 (Kemenkes RI, 2020b). In Indonesia, COVID-19 cases as of the end of March 2021 have been confirmed positive for 1,492,002 cases with deaths reaching 40,364 people (CFR 2.70

Clean and healthy living behaviors, especially washing hands with soap, are one of the main focuses during the COVID-19 pandemic, especially in elementary school-aged children. Therefore, researchers are interested in researching "Factors Related to Handwashing Behavior Using Elementary School-Aged Children's Soap during the COVID-19 Pandemic in RT.008 / RW.007, Pisangan, Ciputat Timur In 2021.

\section{METHODS}

This research is Quantitative Analytics research, with a cross-sectional study design. The study sample was 86 people using total sampling. The analysis conducted in this study was a univariate analysis to look at the prevalence and analysis of chi-square bivariate $(\alpha=0.05)$ and odds ratio (OR) calculations.

\section{HASIL}

Tabel 1. Analisis Univariat

\begin{tabular}{lcc}
\hline \multicolumn{1}{c}{ Variable } & N & \% \\
\hline Gender & 39 & 45,3 \\
Man & 47 & 54,7 \\
Woman & 28 & 32,6 \\
Ages & 58 & 67,4 \\
$<9$ years & & \\
$>9$ years & & \\
Handwashing Behavior using & 25 & 29,1 \\
Soap & 61 & 70,9 \\
Not good & & \\
Good & 20 & 23,3 \\
Knowledge & 66 & 76,7 \\
Not good & & \\
Good & 4 & 4,7 \\
Attitude & 82 & 95,3 \\
Unsupported & & 17,4 \\
Support & 15 & 82,6 \\
Facilities & 71 & 46,5 \\
Not good & & 53,5 \\
Good & 40 & \\
Role of Parents & 46 & \\
Less active & Active &
\end{tabular}


In this study based on the data above, it can be known the distribution of gender respondents from a total of 86 respondents, the majority of respondents are female, namely as many as 47 people (54.7\%), while respondents of the male sex are as many as 39 people (45.3\%). Based on the data above, it can be known the distribution of age from a total of 86 respondents, the majority of respondents have a $>9$ years old, which is as many as 58 people $(67.4 \%)$, while respondents who have a $<$ age of 9 years, which is as many as 28 people (32.6\%). The median value of this variable is 9 . Based on the data above, it can be known the distribution of HandWashing Behavior Using Soap from a total of 86 respondents, the majority of respondents have good behavior, which is as many as 61 people (70.9\%), while respondents who have bad behavior are as many as 25 people (29.1\%). Based on the data above, it can be known the distribution of Knowledge from a total of 86 respondents, the majority of respondents have good knowledge, namely as many as 66 people (76.7\%), while respondents who have bad knowledge are as many as 20 people (23.3\%).

Based on the data above, it can be known the distribution of attitudes from a total of 86 respondents, the majority of respondents have a supportive attitude of 82 people (95.3\%), while respondents who have an attitude of not supporting as many as 4 people (4.7\%). Distribution of facilities from a total of 86 respondents, the majority of respondents have good facilities, namely as many as 71 people (82.6\%), while respondents who have bad facilities are as many as 15 people $(17.4 \%)$. Based on the data above, it can be known the distribution of Parental Roles from a total of 86 respondents, the majority of respondents have active parents, namely as many as 46 people (53.5\%), while respondents who have parents play a less active role, namely as many as 40 people $(46.5 \%)$.

The result of the analysis of the relationship between knowledge and handwashing behavior using soap found that respondents with good knowledge there were as many as 51 people $(77.3 \%)$ who had good handwashing behavior using soap. While among respondents with bad knowledge, there were as many as 10 people (50.0\%) who had good handwashing behavior using soap. The results of the Chi-Square statistical test with continuity correction test (a) obtained a value of $\mathrm{p}=$ 0.038 then it can be concluded that there is a difference in the proportion of handwashing behavior using soap between respondents who have bad knowledge with those who have good knowledge (it can also be concluded: there is a significant relationship between knowledge and handwashing behavior using soap). From the results of the analysis obtained also the value of OR (Odds Ratio) = 3.4 means that respondents with good knowledge have a 3.4 times chance of having good handwashing behavior using soap compared to respondents with bad knowledge.

The results of the analysis of the relationship between attitudes and shop washing behavior were obtained that respondents with a supportive attitude there were as many as 60 people $(73.2 \%)$ who had good handwashing behavior using soap. While among respondents with a poor attitude, there 
E-ISSN: 2808-5361

http://e-journal.fkmumj.ac.id/
Proceeding The First Muhammadiyah InternasionalPublic Health and Medicine Conference

were as many as 1 person (25.0\%) who had good handwashing behavior using soap. The results of the Chi-Square statistical test with continuity correction test (a) obtained a value of $p=0.132$ it can be concluded that there is no difference in the proportion of handwashing behavior using soap between respondents who have an unsupportive attitude and those who have a supportive attitude (it can also be concluded: there is no significant relationship between attitudes and soap handwashing behavior). From the results of the analysis obtained also the value of OR (Odds Ratio) $=8.1$ means that respondents with a supportive attitude have a chance of tending to have good handwashing behavior using soap compared to respondents with an unsupportive attitude.

The results of the analysis of the relationship between facilities and handwashing behavior using soap were obtained that respondents with good facilities there were as many as 60 people (84.5\%) who had good handwashing behavior using soap. While among respondents with bad facilities there were as many as 1 people $(6.7 \%)$ who had good handwashing behavior using soap. The results of the Chi-Square statistical test with continuity correction test (a) obtained a value of $\mathrm{p}=$ 0.000 then it can be concluded that there is a difference in the proportion of handwashing behavior using soap between respondents who have facilities that are not good and those who have good facilities (it can also be concluded: there is a significant relationship between facilities and handwashing behavior using soap). From the results of the analysis obtained also the value of OR $($ Odds Ratio $)=76.3$ means that respondents with good facilities have a 76.3 times chance of having good handwashing behavior using soap compared to respondents with bad facilities.

The results of the analysis of the relationship between the role of parents and the behavior of handwashing using soap were obtained that respondents with active parental roles there were as many as 39 people (84.8\%) who had good handwashing behavior using soap. While among respondents with the role of parents are less active there are as many as 22 people (55.0\%) who have good handwashing behavior using soap. The results of the Chi-Square statistical test with continuity correction test (a) obtained a value of $p=0.005$ then it can be concluded that there is a difference in the proportion of handwashing behavior using soap between respondents who have a less active parental role and those who have an active parental role (it can also be concluded: there is a significant relationship between the role of parents and the behavior of handwashing using soap). From the results of the analysis obtained also the value of OR (Odds Ratio) $=4.5$ means that respondents with active parental roles have a 4.5 times chance of having good soap washing behavior compared to respondents with less active parental roles.

The results of the analysis of the relationship between knowledge and handwashing behavior using soap found that respondents with good knowledge there were as many as 51 people $(77.3 \%)$ who had good handwashing behavior using soap. While among respondents with bad knowledge, there were as many as 10 people $(50.0 \%)$ who had good handwashing behavior using soap. The results of the Chi-Square statistical test with continuity correction test (a) obtained a value of $\mathrm{p}=$ 
E-ISSN: 2808-5361

http://e-journal.fkmumj.ac.id/
Proceeding The First Muhammadiyah InternasionalPublic Health and Medicine Conference

0.038 then it can be concluded that there is a difference in the proportion of handwashing behavior using soap between respondents who have bad knowledge with those who have good knowledge (it can also be concluded: there is a significant relationship between knowledge and handwashing behavior using soap).

According to Mubarak (2011) someone who has a high level of knowledge, especially in terms of handwashing, will encourage someone to apply the knowledge possessed in the form of behavior or actions. Knowledge such as the benefits of handwashing, handwashing moments, and the consequences of not washing hands, so that a person will tend to avoid the consequences of not washing hands and start applying proper handwashing.

This is by research conducted by Kartika et al., (2016) on Sambiroto State Elementary School Students 01 Semarang City showed that respondents who had good handwashing behavior using soap, more commonly found in well-informed respondents $(65.0 \%)$ with the Chi-Square test showing a pvalue of 0.025 . Because the $\mathrm{p}$-value $<0.05$, it can be concluded that $\mathrm{H} 0$ was rejected, meaning there is a relationship between the respondent's knowledge and the behavior of handwashing using soap.

The results of this study are also supported by the results of research conducted by Livana et al., (2020) on students of Panca Karsa Purna Jaya Elementary School in Simpang Pematang District of Mesuji Regency that between knowledge and behavior of handwashing using soap has a significant relationship ( $\mathrm{p}$-value $=0.000$ ) and explained that students whose knowledge is less good are likely to have handwashing behavior using soap that is Less good by 8 times compared to students who have good knowledge. The results of the research of Mukminah et al., (2016) in elementary students in the Working Area of Banyuurip Purworejo Health Center in line with the research of Kartika et al., (2016) and Livana et al., (2020) that there is a significant relationship and the behavior of handwashing using soap in good elementary school students, more and more respondent groups with good knowledge.

The results of the analysis of the relationship between attitudes and soap-washing behavior were obtained that respondents with a supportive attitude there were as many as 60 people $(73.2 \%)$ who had good handwashing behavior using soap. While among respondents with a poor attitude, there were as many as 1 person (25.0\%) who had good handwashing behavior using soap. The results of the Chi-Square statistical test with continuity correction test (a) obtained a value of $p=0.132$ it can be concluded that there is no difference in the proportion of handwashing behavior using soap between respondents who have an unsupportive attitude and those who have a supportive attitude (it can also be concluded: there is no significant relationship between attitudes and soap handwashing behavior).

This is in line with research by Kartika et al., (2016) which stated there was no association between respondents' attitudes and soap washing behavior with the Chi-Square test showing a p-value of > of 0.05 of 0.076. This study is supported again by research Effendi et al., (2019), based on the results of statistical tests found that there is no significant relationship between attitudes with 
handwashing behavior using soap with a p-value > of 0.05 of 0.625 . This study is supported again by Monica et al. research, (2014), based on the results of chi-square statistical tests, obtained a value of pvalue greater than $\alpha$ which is 0.859 , it can be concluded that there is no relationship between attitudes and handwashing behavior.

The results of this study are not in line with Livana et al., (2020) based on statistical tests that found that there is a significant relationship between attitudes and soap washing behavior with chisquare test results obtained value $\mathrm{p}$-value $=0,000<0.05$.

The results of the analysis of the relationship between facilities and handwashing behavior using soap were obtained that respondents with good facilities there were as many as 60 people $(84.5 \%)$ who had good handwashing behavior using soap. While among respondents with bad facilities there were as many as 1 people $(6.7 \%)$ who had good handwashing behavior using soap. The results of the Chi-Square statistical test with continuity correction test (a) obtained a value of $\mathrm{p}=$ 0.000 then it can be concluded that there is a difference in the proportion of handwashing behavior using soap between respondents who have facilities that are not good and those who have good facilities (it can also be concluded: there is a significant relationship between facilities and handwashing behavior using soap). This is in line with Research Nufus \& Tahlil (2017) that there is a relationship between facility availability and handwashing behavior in elementary school-aged children with the Chi-Square test showing a p-value of $>$ of 0.05 of 0.002 .

The results of the research of Mukminah et al., (2016) in elementary school students in the Working Area of Banyuurip Purworejo Health Center in line with the research (Nufus \& Tahlil, 2017) the results of statistical tests with the Chi-Square Test showed a p-value of 0.046 , meaning there is a relationship between the availability of facilities and the behavior of handwashing using soap. This research is supported again by Nugroho's research (2014) from chi-square test statistics obtained pvalue $=0.000$, meaning there is a meaningful relationship between facilities and handwashing behavior using soap. This is by the theory according to Notoatmodjo (2012) that knowledge and attitude alone have not guaranteed the occurrence of the behavior, because there are still necessary facilities or facilities to allow or support the occurrence of such behavior.

The results of this study are not in line with the Kartika et al., (2016) The results of statistical tests with the Chi-Square test showed a p-value of 0.383 . Because the p-value $>0.05$, it can be concluded that $\mathrm{HO}$ is accepted, meaning there is no relationship between the facility and the behavior of handwashing using soap.

The results of the analysis of the relationship between the role of parents and the behavior of handwashing using soap were obtained that respondents with active parental roles there were as many as 39 people (84.8\%) who had good handwashing behavior using soap. While among respondents with the role of parents are less active there are as many as 22 people (55.0\%) who have good handwashing behavior using soap. The results of the Chi-Square statistical test with continuity correction test (a) 
obtained a value of $\mathrm{p}=0.005$ then it can be concluded that there is a difference in the proportion of handwashing behavior using soap between respondents who have a less active parental role and those who have an active parental role (it can also be concluded: there is a significant relationship between the role of parents and the behavior of handwashing using soap).

This is in line with Norfai \& Anam research (2017) in SDN National Standards of 4 Banjarmasin City based on statistical tests of the relationship between the role of parents and correct handwashing behavior obtained $\mathrm{p}$-value $=0.000$ thus $\mathrm{p}$-value is less than the value of $\alpha(0.05)$, this means statistically there is a meaningful relationship between the role of parents with correct handwashing behavior. This is by the theory put forward by Luthviatin et al, (2011) which states that receiving support or advice to take health action affects a person in behavior (Health Belief Model). For example, a child will get used to washing his hands using soap if his parents always advise him to perform the behavior.

The results of the study (Nugroho, 2014) in SD Negeri 21 Talang Kelapa Banyuasin Regency in line with Norfai \& Anam research (2017) from chi-square test statistics obtained p-value: 0.000, meaning there is a meaningful relationship between the role of parents and the behavior of handwashing using soap. The results of this study are contrary to the research (Effendi et al., 2019) in SD Negeri 08 Kota Lubuklinggau test results Chi-Square (Continuity correction). Continuity correction test results are obtained with a value of asymp.sig $(p)=(0.996)$. Because the p-value > 0.05 , there is no significant relationship between attitude and handwashing behavior using soap.

\section{Tabel 2. Hasil Analisis Bivariat}

\begin{tabular}{|c|c|c|c|c|c|c|c|c|}
\hline \multirow{3}{*}{ Variable } & \multicolumn{4}{|c|}{$\begin{array}{c}\text { Hand Washing Behavior using } \\
\text { Soap }\end{array}$} & \multirow{2}{*}{\multicolumn{2}{|c|}{ Total }} & \multirow{3}{*}{$\begin{array}{l}\text { OR 95\% } \\
\text { CI }\end{array}$} & \multirow{3}{*}{$P v$} \\
\hline & \multicolumn{2}{|c|}{ Not good } & \multicolumn{2}{|c|}{ Good } & & & & \\
\hline & $\mathbf{N}$ & $\%$ & $\mathbf{N}$ & $\%$ & $\mathbf{N}$ & $\%$ & & \\
\hline Knowledge & & & & & & & & \\
\hline Not good & 10 & $\mathbf{5 0 , 0}$ & 10 & $\mathbf{5 0 , 0}$ & 20 & 100,0 & $3,4 \quad(1,1-$ & 0,038 \\
\hline Good & 15 & 22,7 & 51 & 77,3 & 66 & 100,0 & & \\
\hline Sikap & & & & & & & & \\
\hline Unsupported & 3 & $\mathbf{7 5 , 0}$ & 1 & 25,0 & 4 & 100,0 & 8,1 (0,8- & 0,132 \\
\hline Supported & 22 & 26,8 & 60 & 73,2 & 82 & 100,0 & & \\
\hline Facilities & & & & & & & & \\
\hline Not good & 14 & 93,3 & 1 & 6,7 & 15 & 100,0 & $76,3(9,0-$ & 0,000 \\
\hline Good & 11 & 15,5 & 60 & 84,5 & 71 & 100,0 & & \\
\hline Parents role & & & & & & & & \\
\hline Less active & 18 & 45,0 & 22 & 55,0 & 40 & 100,0 & $4,5(1,0-$ & 0,005 \\
\hline Active & 7 & 15,2 & 39 & 84,8 & 46 & 100,0 & & \\
\hline
\end{tabular}

\section{CONCLUSION AND SUGGESTION}

Based on the results of a study conducted on 86 respondents, researchers concluded that the related factor in this study is knowledge ( $\mathrm{p}$ value $=0.038 ; \mathrm{OR}=3.4$ ), facility ( $\mathrm{p}$ value $=0.000 ; \mathrm{OR}=$ 
76.3 ), parental role ( $\mathrm{p}$ value $=0.005 ; \mathrm{OR}=4.5$ ). While factors that are not related to the behavior of handwashing using soap are attitudes ( $\mathrm{p}$ value $=0.132 ; \mathrm{OR}=8.1$ ).

It takes an active role for parents to guide, teach and be an example for their children in behaving handwashing using good soap because the family is the main foundation for children in behaving. There needs to be action prevention such as handwashing soap distribution activities and pamphlets containing invitations to wash hands and this activity is shaded by The Banana Health Center.

\section{REFERENCES}

Effendi, S. U., Aprianti, R. and Futubela, S. (2019). Factors Related to Handwashing Behavior Using Soap In Students In Elementary School 08 Lubuk Linggau, Journal of Nursing and Public Health, 7(2), pp. 62-71. doi:10.37676/jnph. v7i2,900.

Kartika, M., Widagdo, L. and Sugihantono, A. (2016). Factors Related to Handwashing Skills in Children Grade IV and V In SDN 179 Rumbai District of Pekanbaru City', Jurnal Ners Indonesia, 4(5), pp. 339-346.Kementerian Kesehatan RI (2014) Perilaku Mencuci Tangan Pakai Sabun Di Indonesia. Available at:https://www.kemkes.go.id/article/view/201410220001/h ari-cuci-tangan-sedunia-2014tangan-bersih- generasi-sehat.html.

Ministry of Health. (2016). Clean and Healthy Living Behavior. Available at: https://promkes.kemkes.go.i d/phbs.

Ministry of Health. (2018a). National Basic Health Research. Available at: https://www.litbang.kemkes.go.id/laporan-riset- health-basic-riskesdas/.

Ministry of Health. (2018b). Banten Province Basic Health Research Available at: http://www.pusat3.litbang.kemkes.go.id.

Ministry of Health (2020) Guidance on Prevention of COVID-19 Transmission for the Community. Available at: https://promkes.kemkes.go.i d/guide-prevention- transmission-covid-19-forcommunity.

Luthviatin, N. and Andrianto, S. (2011). Determinant of clean and healthy living behavior in elementary school students (study in rambipuji village elementary school). FKM University of Jember, pp. 73-74. Available at: http://fkm.unej.ac.id/files/Se mnas2011/08.pdf.

Monica, S., Yosi, M. and Maria, M. (2014). Factors Related to Handwashing Behavior in Elementary School Children 03 Kertajaya Padalarang', Journal of Public Health, 1(1), p.10. Available at: ejournal.stikesborromeus.ac. id/file/journal 5.pdf.

Mubarak, W. I. (2011). Public Health Promotion for Midwifery. Jakarta: Salemba Medika. 
Mukminah, N., Istiarti, V. T. and BM, S. (2016). Factors Related to The Practice of Handwashing Using Soap In Elementary Students In The Working Area of Banyuurip Purworejo's Health Center, Public Health Journal (e-Journal), 4(5), pp. 354-361.

Norfai and Anam, K. (2017). Relationship Between Knowledge, Parental Support and Teacher Support With Correct HandWashing Behavior In Sdn National Standards of 4 Banjarmasin Cities in 2016', Journal of Social Health (Public Health) Equator, 4(3), p. 212. DOI: 10.29406/jkmk.v4i3.852.

Notoatmodjo, S. (2010) Health Behavioral Sciences. Jakarta: Rineka Cipta.

Notoatmodjo, S. (2012). Health promotion and health behavior. Jakarta: Rineka Cipta.

Nufus, H. and Tahlil, T. (2017). Availability of HandWashing Facilities and Behavior in Elementary School-Aged Children', Student Scientific Journal (JIM) Faculty of Nursing, II(3), pp. 1-6.

Nugroho, B. S. (2014). Factors Related to the Application of Handwashing Using Soap in Grade III And Grade IV Elementary School Students Negeri 21 Talang Kelapa Banyuasin Regency', 5(1), pp. 71-76.

PH, L., Setiaji, B. and Fitri, H. (2020). Factors Related to Handwashing Behavior Using Soap on Elementary School Students in Simpang Pematang District of Mesuji District of Lampung Province', 1(1), pp.1-11.

World Health Organization (2020) Hand Hygiene For All. Available at: https://www.who.int/water_ sanitation_health/publications/hand-hygiene-for-all/en/. 